\title{
Incident Irradiance and Cupric Hydroxide Container Treatment Effects on Early Growth and Development of Container-grown Pawpaw Seedlings
}

\author{
Kirk W. Pomper, ${ }^{1}$ Desmond R. Layne, ${ }^{2}$ and Snake C. Jones ${ }^{3}$ \\ Kentucky State University, Land Grant Program, Atwood Research Facility, Frankfort, KY 40601-2355
}

AdDitional INDEX wORDS. Asimina triloba, biomass partitioning, chlorophyll, root to shoot ratio, shade, Kentucky banana, $\mathrm{Cu}(\mathrm{OH})_{2}$

\begin{abstract}
The North American pawpaw [Asimina triloba (L.) Dunal] has great potential as a fruit crop or as a landscape plant. The influence of incident irradiance on pawpaw seedling growth and development in containers was examined in the greenhouse and outdoors. Root spiraling can be a problem for container-grown pawpaw seedlings; therefore, the influence of paint containing cupric hydroxide $\left[\mathrm{Cu}(\mathrm{OH})_{2}\right]$ at $100 \mathrm{~g} \cdot \mathrm{L}^{-1}$ applied to the interior of containers on plant growth was also examined in a greenhouse environment. In pawpaw seedlings grown outdoors for 11 weeks, low to moderate shading levels of $28 \%, 51 \%$, or $81 \%$ increased leaf number, total leaf area, and total plant dry weight (DW) compared to nonshaded seedlings. A shading level of $81 \%$ decreased the root to shoot ratio by half compared to nonshaded plants. Shading of $98 \%$ reduced leaf number, leaf size, and shoot, root, and total plant DW. Shading increased leaf chlorophyll a and b concentrations for pawpaw seedlings grown outdoors, while it decreased average specific leaf $D W\left(\mathbf{m g}^{\circ} \mathrm{cm}^{-2}\right)$. In a separate greenhouse experiment, pawpaw seedlings subjected to shade treatments of $0 \%, 33 \%, 56 \%, 81 \%$, or $98 \%$ did not respond as greatly to shading as plants grown outdoors. Greenhouse-grown plants had greater total and average leaf area under $33 \%$ or $56 \%$ shading than nonshaded plants; however, shading $>56 \%$ reduced root, shoot, and total plant DW. Total shoot DW was greater in greenhouse grown plants with $33 \%$ shading compared to nonshaded plants. Pawpaw seedlings in control and most shade treatments $(33 \%$ to $81 \%)$ in the greenhouse environment had more leaves and greater leaf area, as well as larger shoot, root, and total plant DW than seedlings in similar treatments grown outdoors. The greenhouse environment had a $10 \%$ lower irradiance, a $60 \%$ lower ultraviolet irradiance, and a significantly higher (1.23 vs. 1.20) red to far-red light ratio than the outdoors environment. Treatment of container interiors with $\mathrm{Cu}(\mathrm{OH})_{2}$ decreased total and lateral root DW in nonshaded seedlings, and it adversely affected plant quality by causing a yellowing of leaves and reduction of chlorophyll levels by the end of the experiment in shaded plants. Growth characteristics of pawpaw seedlings were positively influenced by low to moderate shading $(28 \%$ or $51 \%)$ outdoors and low shading $(33 \%)$ in the greenhouse. Seedlings did not benefit from application of $\mathrm{Cu}(\mathrm{OH})_{2}$ to containers at the concentration used in this study. Commercial nurseries can further improve production of pawpaw seedlings using low to moderate shading outdoors.
\end{abstract}

The pawpaw (Asimina triloba) is the largest edible tree fruit native to the United States (Darrow, 1975). With a unique, almost tropical flavored fruit, the pawpaw has great potential as a new high-value fruit crop or for landscape use (Layne, 1996). This plant can be grown successfully in USDA plant hardiness zones 5 (minimum of $-25^{\circ} \mathrm{C}$ ) through 8 (minimum of $-10{ }^{\circ} \mathrm{C}$ ), and its native range covers 26 states from northern Florida to southern Ontario, Canada and as far west as eastern Nebraska and Texas (Kral, 1960). More than 40 pawpaw cultivars are commercially available, either having been selected in the wild or the result of breeding efforts of hobbyists (Jones et al., 1998).

Most commercial nurseries in the United States grow pawpaw trees in containers (1998 Kentucky State University Nursery

\footnotetext{
Received for publication 13 Sept. 2001. Accepted for publication 11 Oct. 2001 This research was supported by U.S. Dept. of Agriculture, Cooperative State Research, Education, and Extension Service agreement no. KYX-10-97-28P. We appreciate participation of high school summer student interns L.N. Peters, B.J. Kundu, and La'Teasa Barnes, who participated in the KSU-USDA 1890 Research and Extension Apprenticeship Program and this project. We thank R. Neal Peterson for supplying seeds used in this study. Technical assistance of E. Reed, Jr., and Terrih-Angelah Turner is also gratefully acknowledged. The cost of publishing this paper was defrayed in part by the payment of the page charges. Under postal regulation, this paper must be hereby marked advertisement solely to indicate this fact.

${ }^{1}$ Corresponding author and principal investigator of horticulture; curator, USDA National Clonal Germplasm Repository for Asimina sp., Kentucky State Univ. ${ }^{2}$ Assistant professor of pomology and extension fruit specialist, Dept. of Horticulture, Box 340375, Clemson Univ., Clemson, SC 29634-0375.

${ }^{3}$ Research assistant, Horticulture Program, Kentucky State University.
}

Survey, unpublished). Although this results in a significantly greater cost to the purchaser, trees usually have a stronger, healthier root system than field-dug seedlings. Recent studies have allowed development of recommendations (e.g., potting medium type, fertilizer regime, and use of tall containers to accommodate the strong taproot of seedlings) toward successful container production of pawpaw, but further improvements in cultural conditions would be advantageous to growers (Finneseth et al., 1998a, 1998b; Jones et al., 1998; Layne, 1996). To allow production of high-value grafted trees, it would be desirable to develop a protocol for rapid container production of seedling rootstocks of pawpaw that would result in a large graftable plant (pencil diameter or $1 \mathrm{~cm}$ diameter stem) in 1 year.

Pawpaw seedlings grown outdoors have been reported to be sensitive to high irradiances upon emergence from the soil, and benefit from partial shading for the first year of development (Gould, 1939). Seedlings produced in greenhouses do not show sensitivity to high light levels, suggesting that seedlings grown outdoors may be sensitive to ultraviolet (UV) radiation (Peterson, 1991). After the first year of growth, pawpaw seedlings are tolerant of full sun, and mature trees will bear large quantities of fruit in an open exposure if properly pollinated.

Plant biomass production and partitioning can be significantly influenced by incident irradiance. Moderate shading of developing sun-preferring plants [e.g., chinese juniper (Juniperus chinensis L. Lindl), japanese euonymous (Euonymus japonica Thunb.), and elaeagnus (Elaeagnus macrophylla Thunb.) decreases root and shoot weight (Whitcomb, 1988). In contrast, shade-prefer- 
ring plants (e.g., rhododendron (Rhododendron L.), english boxwood (Buxus sempervirens L.), and chinese holly (Ilex cornuta Lindl. \& Paxt.)] show increases in root and shoot weight with moderate shading (Whitcomb, 1988). With the shade-preferring plant belgian evergreen (Dracaena sanderana hort Sander ex Mast.), moderate shading decreased the root to shoot ratio and increased plant biomass and leaf area (Vladimirova, 1997). In peach [Prunus persica (L.) Batsch (Peach Group)], shading increased average leaf area, decreased specific leaf weight [SLW; $\mathrm{mg} \cdot \mathrm{cm}^{-2}$, and increased the chlorophyll concentration in leaves (Kappel and Flore, 1983). In apple [Malus sylvestris (L.) Mill var. domestica (Borkh.) Mansf.], shading increased individual leaf area, decreased specific leaf weight, and reduced leaf number (Maggs, 1960). Young and Yavitt (1987) noted that solar irradiance in the understory of eastern deciduous forests, where wild pawpaw trees are usually found, decreased by $85 \%$ when the forest canopy had developed fully. Although pawpaw is native to the shaded environment of the forest understory, optimal light conditions for seedling production in containers have not yet been determined.

A serious problem with transplanting container-grown trees is poor root development (i.e., circling, matted, and kinked roots), which is associated with increased tree mortality (Nichols and Alm, 1983). A water based latex paint containing cupric hydroxide $\left[\mathrm{Cu}(\mathrm{OH})_{2}\right]$ has been used in commercial nurseries to treat the interior surface of containers and successfully reduce root spiraling in several tree species [e.g., river birch (Betula nigra L.), baldcypress (Taxodium distichum (L.) Rich), american plane tree (Platanus occidentalis L.), and weeping willow (Salix babylonica L.)] (Ruter, 1994). Root elongation is inhibited when root tips encounter copper compounds in paint applied to container walls, thus causing lateral branching further back on the root and the formation of a more fibrous root system and a lower root to shoot ratio (Arnold and Struve, 1989, 1993; Arnold and Young, 1991). The lower root to shoot ratio with $\mathrm{Cu}(\mathrm{OH})_{2}$ treatment of containers is the result of a change in dry-matter allocation due to reduced growth of taproots after they contact the bottom of the containers and the subsequent more even vertical distribution of the root systems (Arnold and Struve, 1993). Cupric hydroxide treatment of the interior of containers decreased the root to shoot ratio in West Indian mahogany (Swietinia mahagoni) (Svenson et al., 1995). The root to shoot ratio of green ash (Fraxinus pennsylvanica Marsh.) and red oak (Quercus rubra L.) decreased with use of $\mathrm{CuCO}_{3}$ on the interior surface of containers (Arnold and Struve, 1989).

Since pawpaws are propagated primarily in containers both in the greenhouse and outdoors, the first objective of this study was to determine the influence of incident irradiance on seedling growth and development in both greenhouse and outdoor environments. A second objective was to determine the influence of root-zone modification with $\mathrm{Cu}(\mathrm{OH})_{2}$-treated containers on pawpaw seedling growth and development.

\section{Materials and Methods}

Plant material. For all experiments, pawpaw seeds were harvested in Fall 1995 from open-pollinated half-sib trees at an orchard at the Western Maryland Research and Education Center, Keedysville, Md. Seeds were sown to a $3 \mathrm{~cm}$ depth in moist Pro-Mix 'BX' potting medium (Premier Hort. Inc., Red Hill, Pa.) in $740 \mathrm{~cm}^{3}$ Rootrainers (Hummert Intl., Earth City, Mo.). All seeds were stratified (moist-prechilled) at $5{ }^{\circ} \mathrm{C}$ for at least 3 months prior to sowing. A day/night regime of $25 / 20^{\circ} \mathrm{C}$ was maintained in a $6 \times 9$ $\mathrm{m}$ glass covered greenhouse during seed germination. Seedlings were watered weekly to runoff and were grown in a greenhouse under a $16 \mathrm{~h}$ photoperiod supplemented by high pressure sodium lamps.

GREENHOUSE STUDY (EXPT. 1). A factorial greenhouse experiment was conducted with treatments that included five levels of shade $(0 \%, 33 \%, 56 \%, 81 \%$, and $98 \%)$ and two levels of root-zone treatment [with or without $\mathrm{Cu}(\mathrm{OH})_{2}$ treatment of the interior of containers]. Actual photosynthetic photon flux $(P P F)$ values for shade treatments are found in Table 1 . The treatments were arranged in a split-plot design in two replicated blocks, where the main plot effect was shade, and subplot effect was $\mathrm{Cu}(\mathrm{OH})_{2}$. Experimental treatment combinations had 10 seedlings per replication. Blocks were arranged along the long, north-south axis in the greenhouse.

Before seed sowing, as described above, half of the 40 Rootrainer trays used in this study were treated with a water based latex paint with $\mathrm{Cu}(\mathrm{OH})_{2}$ at $100 \mathrm{~g} \cdot \mathrm{L}^{-1}$ (Spin Out, Griffin Corp., Valdosta, Ga.). Each tray was used to produce 27 seedlings (nine books with three seedling cells per book). Individual books were unfolded and immersed in the latex paint with $\mathrm{Cu}(\mathrm{OH})_{2}$ and allowed to dry completely before moist medium was added. On 11 Apr. 1996, seeds were sown in each cell of the $\mathrm{Cu}(\mathrm{OH})_{2}$-treated and nontreated (control) trays. Seedlings were grown in the greenhouse until they reached the two- to three-leaf stage on 16 June 1996, when seedling number per 27 -cell tray was reduced to the most uniform 10 by excising the remaining plants at the soil line. Following roguing, all seedlings were moved to a different $6 \times 9 \mathrm{~m}$ greenhouse with days/ nights of $29 \pm 3 / 24 \pm 2{ }^{\circ} \mathrm{C}$. This greenhouse had clean, clear glass walls and roof (not whitewashed), and no supplemental irradiation was supplied in it or the adjacent houses during the duration of the study. Four trays (two from each root-zone modification treatment)

Table 1. Environmental conditions for pawpaw seedlings grown outdoors or in the greenhouse under selected shading treatments.

\begin{tabular}{|c|c|c|c|c|c|c|c|c|c|c|}
\hline \multirow[b]{2}{*}{ Shade $(\%)$} & \multicolumn{2}{|c|}{$\begin{array}{l}\text { Photosynthetic } \\
\text { photon flux } \\
\left(\mu \mathrm{mol} \cdot \mathrm{m}^{-2} \cdot \mathrm{s}^{-1}\right)\end{array}$} & \multicolumn{2}{|c|}{ Shade $(\%)$} & \multicolumn{2}{|c|}{ Temp $\left({ }^{\circ} \mathrm{C}\right)$} & \multicolumn{2}{|c|}{$\begin{array}{l}\text { Red to far-red } \\
\text { light ratio }\end{array}$} & \multicolumn{2}{|c|}{$\begin{array}{c}\text { Ultraviolet } \\
\text { light } \\
\left(\mu \mathrm{mol} \cdot \mathrm{m}^{-2} \cdot \mathrm{s}^{-1}\right)\end{array}$} \\
\hline & Outdoors & Greenhouse & Outdoors & Greenhouse & Outdoors & Greenhouse & Outdoors & Greenhouse & Outdoors & Greenhouse \\
\hline None & $1478 \mathrm{a}^{\mathrm{z}}$ & $1217 \mathrm{a}$ & 0 & 0 & $24.2 \mathrm{a}$ & 30.8 & 1.21 & 1.23 & $131.5 \mathrm{a}$ & $56.5 \mathrm{a}$ \\
\hline 30 & $1064 \mathrm{~b}$ & $815 \mathrm{~b}$ & 28 & 33 & $24.6 \mathrm{a}$ & 29.4 & 1.21 & 1.23 & $82.5 \mathrm{~b}$ & $34.0 \mathrm{~b}$ \\
\hline 55 & $724 \mathrm{c}$ & $535 \mathrm{c}$ & 51 & 56 & $24.2 \mathrm{a}$ & 28.9 & 1.21 & 1.23 & $59.0 \mathrm{c}$ & $24.5 \mathrm{c}$ \\
\hline 80 & $280 \mathrm{~d}$ & $231 \mathrm{~d}$ & 81 & 81 & $24.5 \mathrm{a}$ & 30.0 & 1.20 & 1.23 & $18.5 \mathrm{~d}$ & $8.0 \mathrm{~d}$ \\
\hline 95 & $30 \mathrm{e}$ & $25 \mathrm{e}$ & 98 & 98 & $28.2 \mathrm{~b}$ & 30.1 & 1.22 & 1.22 & $1.5 \mathrm{e}$ & $0.7 \mathrm{e}$ \\
\hline \multicolumn{11}{|l|}{ Significance } \\
\hline F test & $* * *$ & $* * *$ & --- & --- & $* * *$ & NS & NS & NS & $* * *$ & $* * *$ \\
\hline
\end{tabular}

${ }^{\mathrm{z}}$ Mean separation within columns by LSD at $P<0.05$.

Ns,**** Nonsignificant at $P>0.05$ or significant at $P<0.0001$, respectively. 
were assigned randomly to each of 10 benches that were raised 61 $\mathrm{cm}$ off the greenhouse floor. Shade treatments were assigned randomly to each of the trays under commercially prepared $30 \%$, $55 \%, 80 \%$, or $95 \%$ shade cloth (PAK $100 \%$ polypropylene shade fabric, Hummert, Intl., Earth City, Mo.). Control plants were grown on benches that were not shaded. For each shade treatment, a wooden shade frame $(91 \times 244 \times 91 \mathrm{~cm})$ was affixed to the bench corners. Shade cloth was draped over the frame, cut, and stapled to the frame so that it did not overlap on the top or sides of the frame. A vertical slit was made through the cloth down one long side of each frame to provide access to the seedlings for growth measurements. The slit remained closed otherwise. All seedlings were fertigated twice weekly with $250 \mathrm{mg} \cdot \mathrm{L}^{-1}$ of a $26 \mathrm{~N}-8.6 \mathrm{P}-16.6 \mathrm{~K}$ water-soluble fertilizer also containing trace elements (Peters 20-20-20; Scotts Co., Marysville, Ohio).

On 3 Sept. 1996, height, leaf number, and total leaf area were determined for each plant. Leaf area was measured with a CI-203 portable laser leaf area meter and a CI-203-CA conveyor attachment (C.I.D., Vancouver, Wash.). Roots were washed of attached soil and patted dry with a paper towel. Then lateral roots were trimmed from the taproots. Stems, leaves, lateral roots, and taproots of each plant were dried for at least $48 \mathrm{~h}$ at $50^{\circ} \mathrm{C}$ in a convection oven. Dry weight (DW) was determined gravimetrically using an electronic balance (model A-160; Fischer Scientific, Pittsburgh, Pa.).

OUTDOOR STUDY (EXPT. 2). A randomized compete block design experiment was conducted outdoors with two blocks. Treatments consisted of five levels of shade $(0 \%, 28 \%, 51 \%, 81 \%$, or $98 \%)$, as in the greenhouse study, with 20 seedlings included in each experimental treatment per block. Seeds were sown 29 Apr. 1998, and allowed to germinate in the greenhouse as described previously. Once seedlings in Rootrainers reached the two- to three-leaf stage (11 June 1998), they were placed outdoors, and the same benches and attached shade structures described in the greenhouse study were used to impose the shade treatments. Benches were placed directly on grass in a field far enough from building structures to avoid shading. Control seedlings were not shaded. Blocks were oriented in an east-west orientation on a gentle slope. Plants were watered as needed and fertilized weekly with $250 \mathrm{mg} \cdot \mathrm{L}^{-1}$ of a $20 \mathrm{~N}$ 8.6P-16.6K water-soluble fertilizer containing soluble trace elements (Peters 20-20-20). Plants were destructively harvested on 27 Aug. 1998, 11 weeks after the start of the experiment. Leaf number, seedling height, and leaf area were recorded. Weight of dried stems, leaves, and roots was also determined gravimetrically as described for Expt. 1.

Photosynthetic photon flux, AIR Temperature, AND SPeCTRAL ANALYSIS. At noon on a representative sunny day, four replicate measurements per treatment were made at midcanopy level and recorded for a) $P P F$ (400 to $700 \mathrm{~nm}$ ), using a quantum/radiometer/ photometer with a quantum sensor (LI-185B and Q7072, respectively; LI-COR, Inc., Lincoln, Nebr.), b) red (660 nm) and far-red $(730 \mathrm{~nm})$ light with a portable spectroradiometer (LI-1800), and c) UV light (250 to $400 \mathrm{~nm}$ ) using an ultraviolet meter (Apogee Instruments, Spectrum Technologies, Inc., Plainfield, Ill.). In the greenhouse experiment, air temperatures were measured inside and outside shade structures for each bench at seedling height, using a thermistor thermometer (Digisense; Cole-Parmer, Vernon Hills, Ill.). In the outdoor experiment, the temperature inside and outside shade structures was measured every $30 \mathrm{~min}$ for $24 \mathrm{~h}$ using sensors (TEMP HOBO; Onset Computer Corp., Pocasset, Mass.).

Chlorophyll Determination. At the time of destructive harvest in the greenhouse and outdoor studies, leaf discs were collected from the apical, medial, and basal expanded leaves of each plant.
Four discs $\left(0.32 \mathrm{~cm}^{2}\right.$ each $)$ were removed from the middle of the leaf using a paper hole punch. Discs were extracted in $8 \mathrm{~mL}$ of N,Ndimethylformamide (Sigma, St. Louis, Mo.) in darkness at $5^{\circ} \mathrm{C}$ for at least $36 \mathrm{~h}$. Absorbance of extracts was read at 625,664 , and $647 \mathrm{~nm}$ on a DU-70 UV/Vis spectrophotometer (Beckman Instruments, Fullerton, Calif.). Calculations for chlorophyll (chl) a, chl b, and protochlorophyll (p) chl were made as described by Moran (1982).

Statistical ANaLysis. Data from both studies were subjected to GLM analysis of variance (ANOVA) or stepwise GLM regression analysis using the statistical program Costat (CoHort Software, Minneapolis, Minn.). Where appropriate, treatment means were separated using least significant difference (LSD) or an unpaired $t$ test.

\section{Results}

Greenhouse STUdY (EXPT. 1). Incident light levels were reduced by $33 \%, 56 \%, 81 \%$, and $98 \%$ using the $30 \%, 55 \%, 80 \%$, and $95 \%$ shade fabric, respectively (Table 1). Temperature and red to far-red light ratios were similar in all treatments. UV irradiance declined with increased shading (Table 1).

ANOVA indicated there was a significant interaction between shading and $\mathrm{Cu}(\mathrm{OH})_{2}(P<0.001)$ for total leaf area, average leaf area, average plant SLW, lateral root DW, and total root, shoot, and plant DW. In plants without container treatment with $\mathrm{Cu}(\mathrm{OH})_{2}$, leaf number showed a quadratic response with increasing shade level, with plants under $81 \%$ or $98 \%$ shade exhibiting a decline in leaf number compared

Fig. 1. Effect of shading and treatment of containers with (open symbols) and without (closed symbols) cupric hydroxide $\left[\mathrm{Cu}(\mathrm{OH})_{2}\right]$ on growth of pawpaw seedlings in the greenhouse. (A) Leaf number of plants with $(\mathrm{y}=13.632+0.135 \mathrm{x}-$ $\left.0.002 \mathrm{x}^{2}, R^{2}=0.89, P=0.001\right)$ and without $\mathrm{Cu}(\mathrm{OH})_{2}(\mathrm{y}=$ $14.938+0.1655 \mathrm{x}-0.002 \mathrm{x}^{2}, R^{2}$ $=0.92, P=0.001),(\mathbf{B})$ average leaf area in plants with $(\mathrm{y}=$ $34.22+1.08 \mathrm{x}-0.01 \mathrm{x}^{2}, R^{2}=$ $0.64, P=0.001)$ and without $\mathrm{Cu}(\mathrm{OH})_{2}(\mathrm{y}=28.01+0.89 \mathrm{x}-$ $\left.0.01 \mathrm{x}^{2}, R^{2}=0.68, P=0.001\right)$, and $(\mathbf{C})$ average plant specific leaf DW (SLW) in plants with $\left(\mathrm{y}=4.160-0.017 \mathrm{x}-0.001 \mathrm{x}^{2}\right.$ $\left.R^{2}=0.78, P=0.04\right)$ and without $\mathrm{Cu}(\mathrm{OH})_{2}(\mathrm{y}=4.216-0.035 \mathrm{x}+$ $\left.0.001 \mathrm{x}^{2}, R^{2}=0.98, P=0.001\right)$ Each symbol is the mean of two blocks \pm sE. Indicates that means were significantly different between $\mathrm{Cu}(\mathrm{OH})_{2}$ treated and non-treated plants using an unpaired $t$ test $(P<$ $0.05, \mathrm{n}=2$ ).
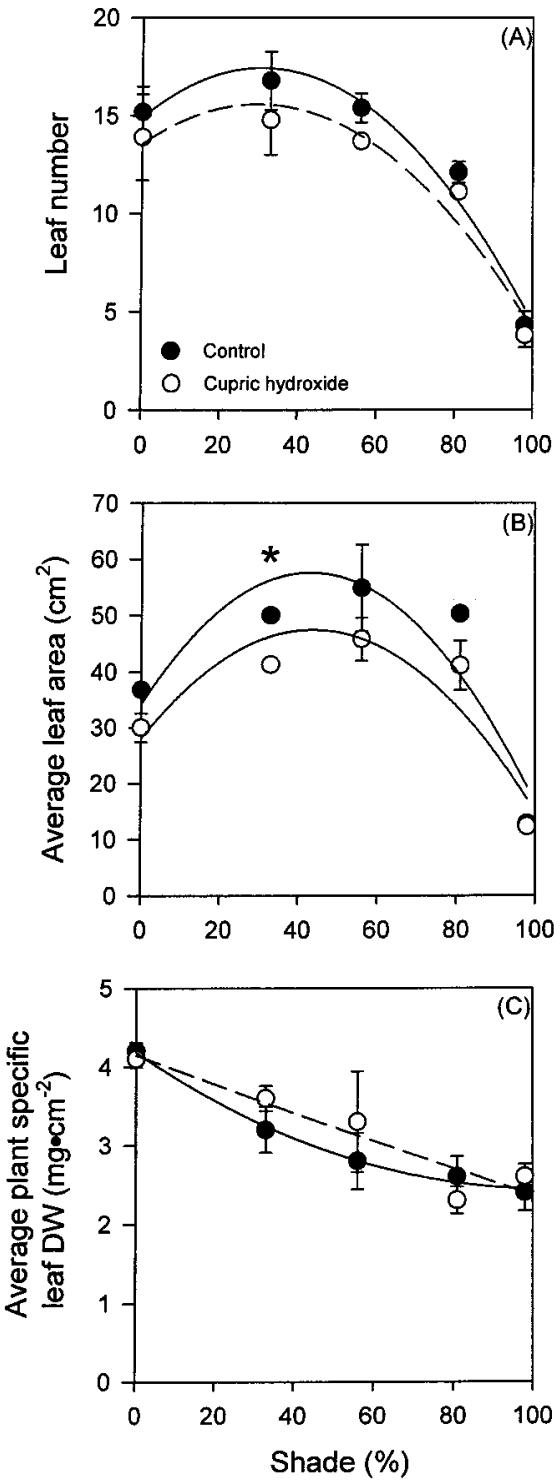
to nonshaded plants (Fig. 1A). Average plant leaf area also showed a similar quadradic response to shading, as did total leaf area (data not presented), but with greater average leaf area in plants with $33 \%$ or $56 \%$ shading, and reduced leaf area at $98 \%$ shading, compared to nonshaded plants (Fig. 1B). Average plant SLW declined with shading, showing a quadratic response curve (Fig. 1C). Shoot, root, lateral root, and plant DW were similar with $0 \%$, 33\%, or $56 \%$ shading, but declined with $81 \%$ or $98 \%$ shading, resulting in a quadratic response curve to shading (Fig. 2A, B, and C). Total shoot DW was greater in plants with $33 \%$ shading compared to nonshaded plants (Fig. 2A). Root to shoot ratio of control plants was reduced with shading of $33 \%, 56 \%$, or $81 \%$ compared to nonshaded plants, but increased in plants with $98 \%$ shading, showing a quadratic response curve (Fig. 2D).

Plants in containers treated with $\mathrm{Cu}(\mathrm{OH})_{2}$ also showed a similar quadratic response to shading to that of nontreated plants in terms of leaf number, average leaf area, total leaf area, average plant SLW,

Fig. 2. Effect of shading and treatment of containers with (open symbols) and without (closed symbols) cupric hydroxide $\left[\mathrm{Cu}(\mathrm{OH})_{2}\right]$ on biomass production by pawpaw seedlings grown in the greenhouse. (A) Shoot DW of plants with (y $\left.=2.670+0.049 \mathrm{x}-0.001 \mathrm{x}^{2}, R^{2}=0.98, P=0.001\right)$ and without $\mathrm{Cu}(\mathrm{OH})_{2}(\mathrm{y}=3.409$ $\left.+0.046 \mathrm{x}-0.001 \mathrm{x}^{2}, R^{2}=0.96, P=0.001\right),(\mathbf{B})$ total root DW in plants with $(\mathrm{y}$ $\left.=2.842+0.028 \mathrm{x}-0.001 \mathrm{x}^{2}, R^{2}=0.98, P=0.001\right)$ and without $\mathrm{Cu}(\mathrm{OH})_{2}(\mathrm{y}=3.207$ $\left.-0.002 \mathrm{x}-0.001 \mathrm{x}^{2}, R^{2}=0.96, P=0.003\right)$, and for lateral root $\mathrm{DW}$ for plants with $\left(\mathrm{y}=0.549+0.006 \mathrm{x}-0.001 \mathrm{x}^{2}, R^{2}=0.97, P<0.001\right)$ and without $\mathrm{Cu}(\mathrm{OH})_{2}(\mathrm{y}=$ $\left.0.710-0.001 \mathrm{x}-0.001 \mathrm{x}^{2} R^{2}=0.98, P<0.007\right),(\mathbf{C})$ total plant DW in plants with $\left(\mathrm{y}=5.512+0.770 \mathrm{x}-0.001 \mathrm{x}^{2}, R^{2}=0.96, P=0.001\right)$ and without $\mathrm{Cu}(\mathrm{OH})_{2}(\mathrm{y}=$ $\left.6.616+0.043 \mathrm{x}-0.001 \mathrm{x}^{2}, R^{2}=0.96, P=0.001\right)$, and $(\mathbf{D})$ root to shoot ratio in plants with and without $\mathrm{Cu}(\mathrm{OH})_{2}\left(\mathrm{y}=1.016-0.019 \mathrm{x}+0.001 \mathrm{x}^{2}, R^{2}=0.57, P=\right.$ $0.004)$. Each symbol is the mean of two blocks \pm SE. * Indicates that means were significantly different between $\mathrm{Cu}(\mathrm{OH})_{2}$ treated and nontreated plants using an unpaired $t$ test $(P<0.05, \mathrm{n}=2)$.
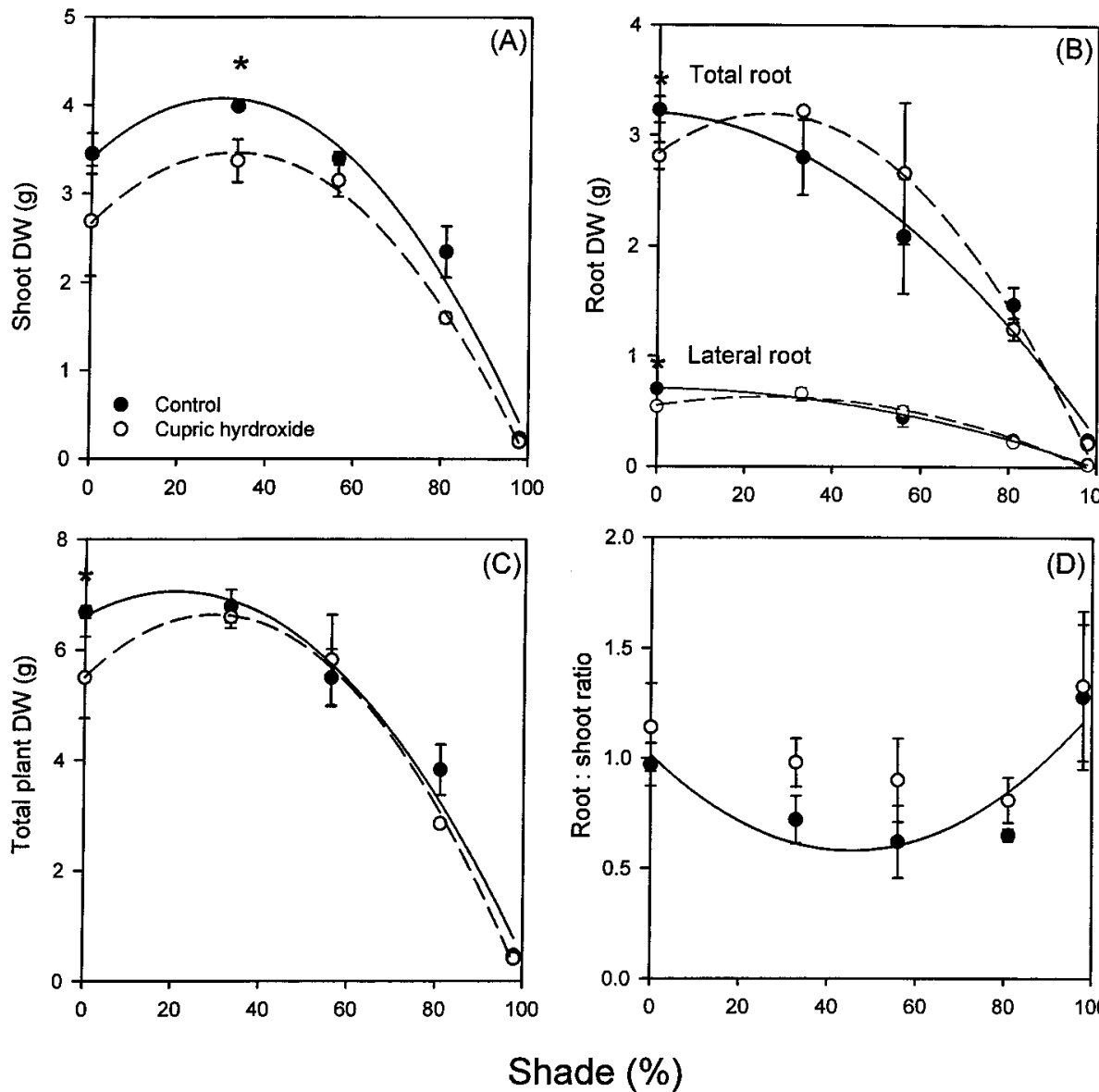

shoot DW, root DW, lateral root DW, and total plant DW. Leaf number and average SLW were similar in control and $\mathrm{Cu}(\mathrm{OH})_{2}$ treated plants (Fig 1A and B). Cupric hydroxide treated plants had decreased average leaf area at $33 \%$ shading, compared to nontreated plants (Fig. 1C). Although not significant, there was a trend toward a reduction in shoot $\mathrm{DW}$ in $\mathrm{Cu}(\mathrm{OH})_{2}$ treated plants at $0 \%$ or $33 \%$ shading compared to nontreated plants (Fig. 2A). Root DW and lateral root $\mathrm{DW}$ were reduced in $\mathrm{Cu}(\mathrm{OH})_{2}$-treated plants at $0 \%$ shading compared to nontreated plants (Fig. 2B). Total plant DW was reduced in $\mathrm{Cu}(\mathrm{OH})_{2}$-treated plants at $0 \%$ shading compared to nontreated plants (Fig. 2B). Root to shoot ratio was similar in $\mathrm{Cu}(\mathrm{OH})_{2}$-treated and nontreated plants (Fig. 2D).

Leaf chl a, b, p, and total chl concentration was not affected by shading of plants that did not have containers treated with $\mathrm{Cu}(\mathrm{OH})_{2}$; however, chl a to $\mathrm{b}$ ratio showed a negative linear response to increasing shading (Fig. 3). In contrast, $\mathrm{Cu}(\mathrm{OH})_{2}$-treated plants showed a negative linear response to shading on leaf chl a, b, p, and total chl concentration (Fig. 3). Leaf chl a, b, p, and total chl concentration in $\mathrm{Cu}(\mathrm{OH})_{2}$-treated plants were all lower than nontreated plants under $33 \%, 56 \%$, or $81 \%$ shading (Fig. 3).

OUTDOOR STUDY (EXPT. 2). Incident light levels were reduced by $28 \%, 51 \%, 81 \%$, and $98 \%$ for the $30 \%, 55 \%, 80 \%$, and $95 \%$ shade fabric treatments, respectively (Table 1). Red to far-red light ratio was the same for all treatments; however, UV irradiance declined with increased shading (Table 1). Average daily air temperature was higher in the $95 \%$ shade treatment, than in the other shade treatments. Incident light levels $(P P F)$ were about $10 \%$ higher outdoors than in the greenhouse and UV light levels were $\approx 2$-fold higher outdoors than in the greenhouse. Air temperature was $\approx 5^{\circ} \mathrm{C}$ higher in the greenhouse than outdoors.

In plants grown outdoors, leaf number showed a quadratic response to increasing shade level, with plants showing increased leaf number at $28 \%, 51 \%$, or $81 \%$ shading over nonshaded plants (Fig. 4A). Plants in the $98 \%$ shade level produced the fewest leaves. Plants were taller under $28 \%, 51 \%$, or $81 \%$ shading than in nonshaded plants (unpaired $t$ test, $P<$ $0.05, \mathrm{n}=2$, Fig. 4A). Leaf area was greater at $28 \%, 51 \%$, or $81 \%$ shading than in nonshaded plants; plants at $95 \%$ shading had reduced leaf area compared to nonshaded plants (unpaired $t$ test, $P<0.05, \mathrm{n}=2$; Fig. 4B). Average plant SLW declined with shading, showing a quadratic response curve (Fig. 4C). Total shoot, root, and plant DW increased under $28 \%, 51 \%$, or $81 \%$ shading, but declined with $98 \%$ shading, resulting in a quadratic response curve to shading (Fig. 5A, B, and C). Root to shoot ratio was reduced only at $81 \%$ shading when compared to nonshaded plants (Fig. 5D). Seedlings showed a positive quadratic response to shading for leaf chl a, $\mathrm{p}$, and total chl concentration (Fig. 6A). Leaf chl b concentration increased with $28 \%, 51 \%$, or $81 \%$ shading (Fig. 6A). In contrast to plants grown in the greenhouse, there was a positive linear response in chl a to b ratio with increased shading outdoors (Fig. 6B).

About 4 weeks after the seedlings were placed outdoors, nonshaded seedlings in one block were completely defoliated by caterpil- 

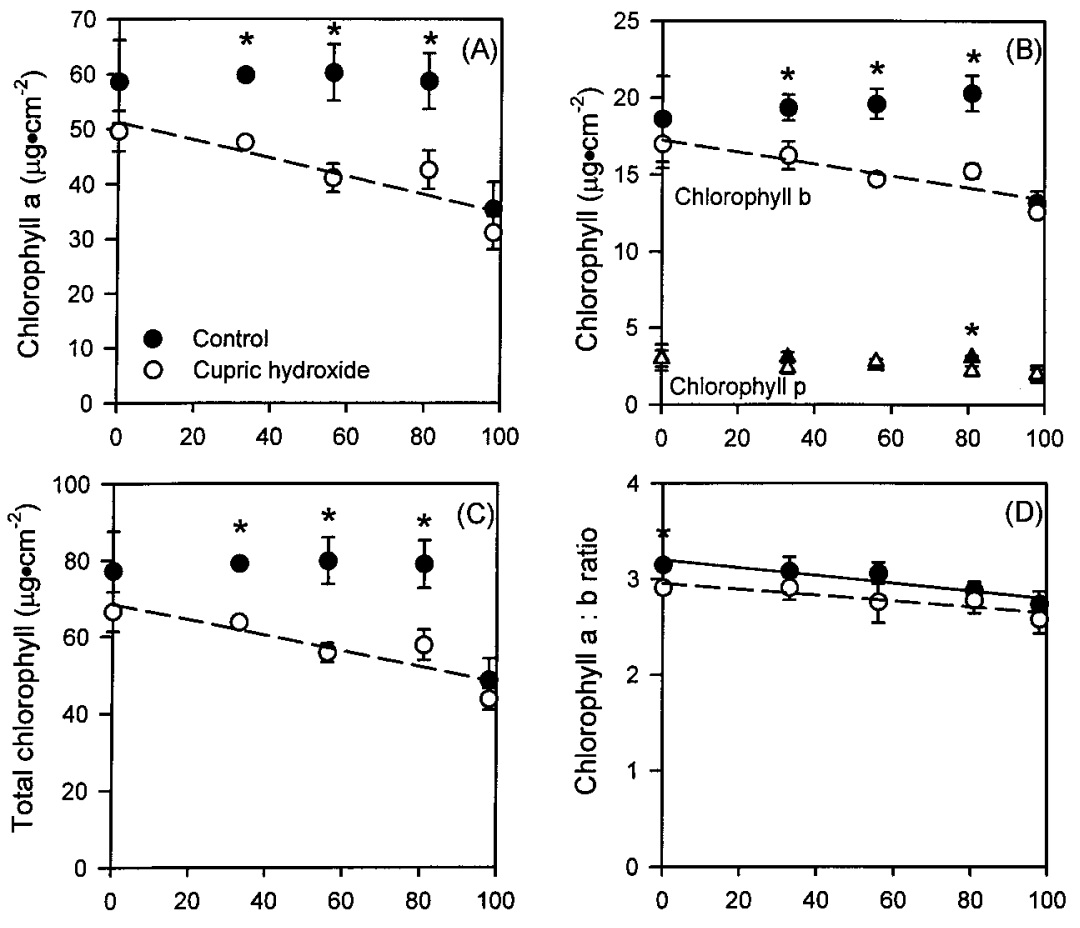

Shade (\%)

Fig. 3. Effect of shading and treatment of containers with (open symbols) and without (closed symbols) cupric hydroxide $\left[\mathrm{Cu}(\mathrm{OH})_{2}\right]$ on leaf chlorophyll (chl) concentration in pawpaw seedlings grown in the greenhouse. (A) Leaf chl a in plants with $\left(\mathrm{y}=50.67-0.14 \mathrm{x}, R^{2}=0.71, P=0.002\right)$ and without $\mathrm{Cu}(\mathrm{OH})_{2},(\mathbf{B})$ chl b in plants with $\left(\mathrm{y}=17.02-0.03 \mathrm{x}, R^{2}=0.72, P=0.001\right)$ and without $\mathrm{Cu}(\mathrm{OH})_{2}$, and chl p for plants with and without $\mathrm{Cu}(\mathrm{OH})_{2}$, and $(\mathbf{C})$ total chl for plants with $\left(\mathrm{y}=67.70-0.17 \mathrm{x}, R^{2}=0.71, P=0.001\right)$ and without $\mathrm{Cu}(\mathrm{OH})_{2}$, and (D) chl a to b ratio for plants with $\left(\mathrm{y}=2.958-0.003 \mathrm{x}, R^{2}=0.70, P=0.001\right)$ and without $\mathrm{Cu}(\mathrm{OH})_{2}\left(\mathrm{y}=3.200-0.004 \mathrm{x}, R^{2}=0.83, P=0.001\right)$. Each symbol is the mean of two blocks \pm SE. *Indicates that means were significantly different between $\mathrm{Cu}(\mathrm{OH})_{2}$ treated and nontreated plants using an unpaired $t$ test $(P<$ $0.05, \mathrm{n}=2)$.

lars of the zebra swallowtail butterfly (Eurytides marcellus Cramer). The caterpillars were removed weekly from any plant, thereafter. The seedlings in this block recovered well and by the time of destructive harvest were similar in size and other attributes to seedlings in the other block (data not presented).

\section{Discussion}

The structure and physiology of a developing plant can be affected profoundly by the quantity and quality of light incident upon the plant (Buisson and Lee, 1993; Givinish, 1988; Rajapakse et al., 1999). When pawpaw seedlings were grown outdoors, they responded to low to moderate shading with increased production of both root and shoot biomass, as reported in other shadepreferring plants at similar shade levels (Vladimirova et al., 1997; Whitcomb, 1988). Prior to this study, common thought suggested that full sun was lethal to pawpaw seedlings. Nonshaded seedlings survived in this study; however, they accumulated about half the biomass of seedlings receiving $28 \%$ to $81 \%$ shading. Only heavy shading outdoors altered root to shoot partitioning in pawpaw, with $81 \%$ shading lowering the root to shoot ratio. A reduction in the root to shoot ratio is believed to maximize growth in light-limited environments and confer shade tolerance to a plant (Abrams and Kubiske, 1990; Givinish, 1988).
Young and Yavitt (1987) reported that proximal pawpaw leaves, which developed before the overstory forest canopy closed, were $76 \%$ smaller than distal leaves that developed after canopy closure. In the present investigation, seedlings in the outdoor study displayed an even greater increase in leaf area with low to moderate shading than noted by Young and Yavitt (1987). Partial shading has been reported to increase leaf area in both shade-preferring (Vladimirova et al., 1997) and sun-preferring plants (Givinish, 1988; Kappel and Flore, 1983). Pawpaw seedlings under $28 \%$ to $51 \%$ shading in the outdoor study had more leaves than nonshaded plants. Moderate shading increased the number of leaves in the shade preferring plant Belgian evergreen (Vladimirova et al., 1997), whereas shading of developing apple trees reduced the number of leaves produced (Maggs, 1960). In sun-preferring plants, SLW usually declines with shading (Buisson and Lee, 1993; Kappel and Flore, 1983). Although pawpaw responded in many other ways as a shade-preferring plant, average plant SLW declined with shading.

Shadeleaves generally have ahigherconcentration of chl, especially chl $b$, than sun leaves, thus allowing the shade leaves to use the limited amount of light reaching them (Anderson, 1986; Givinish, 1988). The resulting lower chl a to $\mathrm{b}$ ratio with shading may represent a change in stoichiometry of photosystems I and II (Anderson, 1986; Hidema, et al., 1992). Moderate shading outdoors significantly increased chl a and $b$ concentration in pawpaw seedlings, but interestingly raised chl a to $\mathrm{b}$ ratio (Fig. 6A and B).

Seedlings subjected to low to moderate shading $(33 \%, 56 \%$, or $81 \%$ ) in the greenhouse study also showed increased total leaf area. However, shading of $33 \%$ failed to significantly increase root and total plant DW compared to controls, and shading above $56 \%$ actually decreased root, shoot, and total plant DW production. Total

Fig. 4. Effect of shading on growthofpawpaw seedlings grown outdoors. (A) Leaf number $(\mathrm{y}=7.077+0.180 \mathrm{x}$ $-0.002 \mathrm{x}^{2}, R^{2}=0.76, P=$ 0.001 ) and seedling height, (B) total plant leaf area, and (C) average plant specific leaf dry weight (SLW) (y = $5.712+0.004 \mathrm{x}-0.001 \mathrm{x}^{2}$, $\left.R^{2}=0.97, P=0.001\right)$. Each symbol is the mean of two blocks \pm SE.
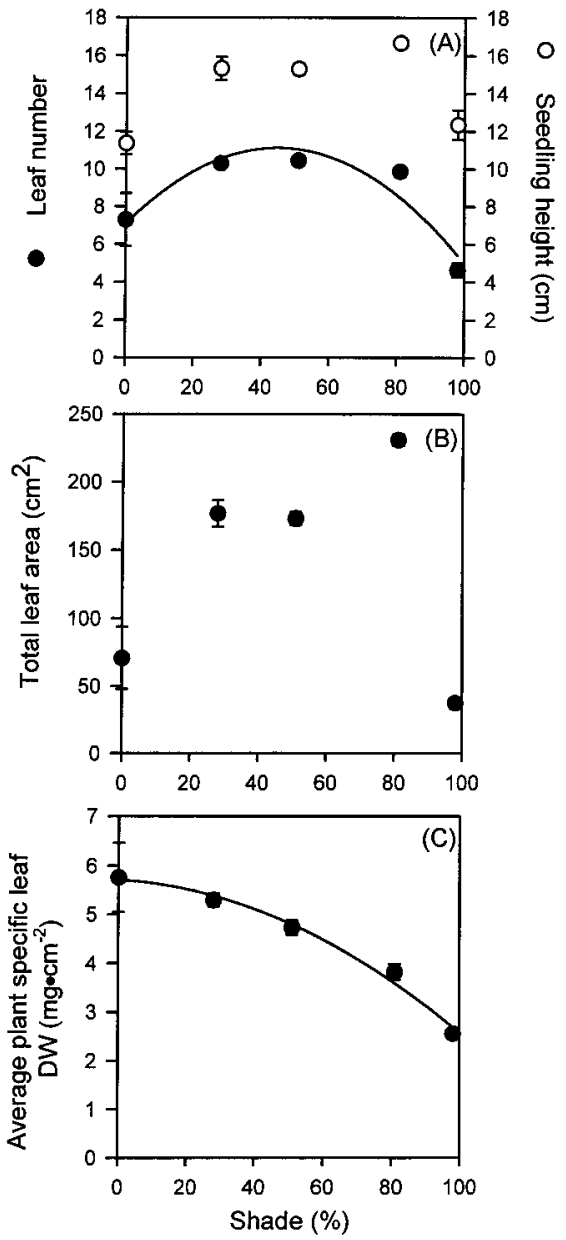

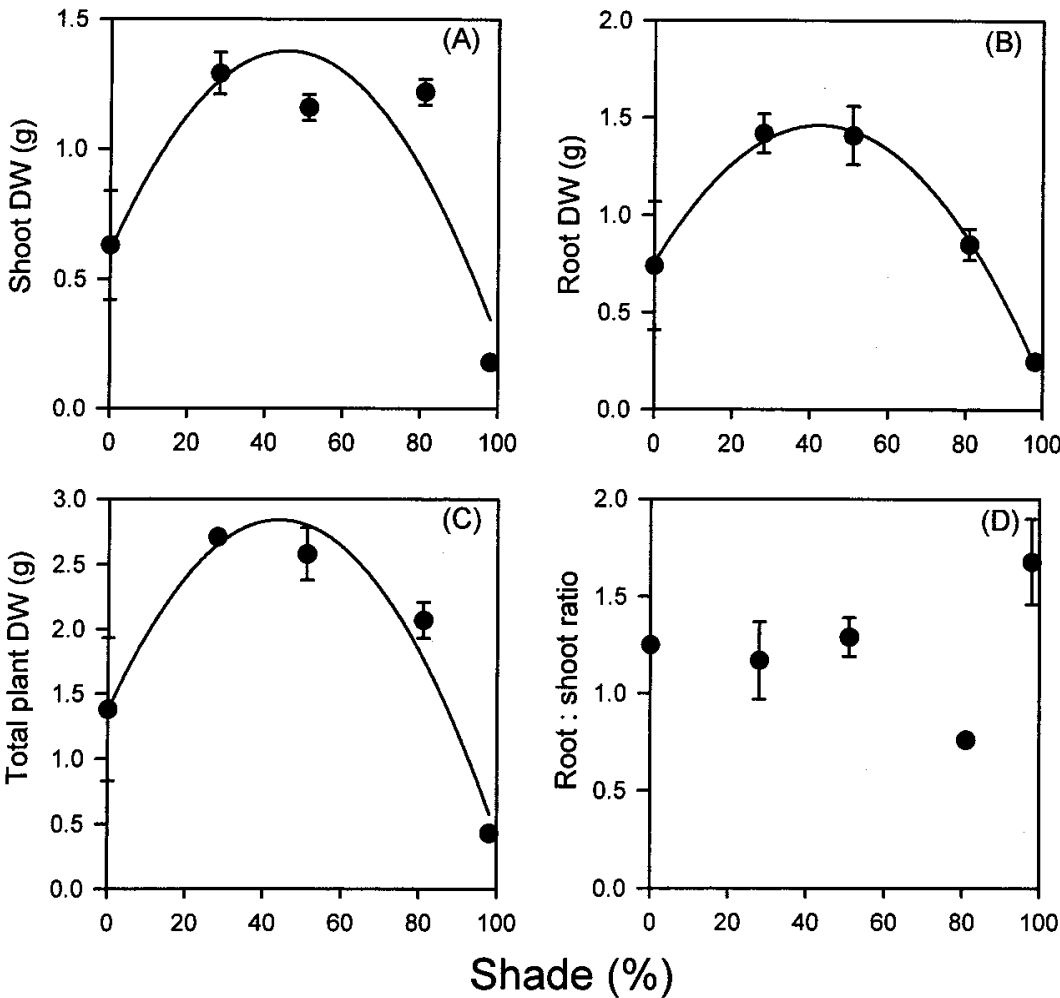

Fig. 5. Effect of shading on biomass production of pawpaw seedlings grown outdoors. (A) Shoot DW (y =0.613 +0.033x $\left.-0.001 \mathrm{x}^{2}, R^{2}=0.62, P=0.001\right)$, (B) total root DW (y =0.758+0.034x $\left.-0.001 \mathrm{x}^{2}, R^{2}=0.98, P=0.001\right),(\mathbf{C})$ total plant DW $\left(\mathrm{y}=1.371+0.067 \mathrm{x}-0.001 \mathrm{x}^{2}, R^{2}=0.90, P=0.001\right)$, (D) root to shoot ratio. Each symbol is the mean of two blocks \pm SE.

shoot DW was greater in greenhouse-grown plants with $33 \%$ shading compared to nonshaded plants. This is in contrast to the response of seedlings to shading in the outdoor study, where $28 \%$, $51 \%$, or $81 \%$ significantly increased root, shoot, and total plant DW compared to the control.

Although plants in the greenhouse study did not respond to shading as in the outdoor study, pawpaw seedlings in corresponding control and shade treatments $(33 \%, 56 \%$, and $81 \%)$ in the greenhouse with or without $\mathrm{Cu}(\mathrm{OH})_{2}$, had more leaves and had greater leaf area, as well as larger shoot, root, and total plant DW (compare Figs. 2 and 5). The greater growth of greenhouse-grown plants may have been due to twice weekly fertigation compared to weekly fertigation of plants outdoors. Altered red to far-red light ratios can affect phytochrome-mediated processes and can profoundly affect plant growth and development (Hutchison and Matt, 1977; Lee and Graham, 1987; Morgan and Smith, 1976; Rajapakse et al., 1999; Tasker and Smith, 1976). UV light has been shown to decrease growth in other plants (Gonzalez et al., 1998; Sisson and Caldwell, 1977). In the present study, an artificial shade environment was established utilizing black woven fabric; however; the shade fabric used did not alter the red to far-red light ratio. The greenhouse glass had a small, but significant effect on the red to far-red light ratio, which may have affected plant growth. The greenhouse glass reduced the level of UV light encountered by plants growing in the greenhouse environment, which may also have enhanced growth of pawpaw seedlings in the greenhouse. The shade cloth also significantly reduced UV light levels outdoors, resulting in growth enhancement.

Use of copper compounds in containers can cause lateral branching and stimulate formation of a more fibrous root system in other container-grown tree species (Arnold and Struve, 1989, 1993). Root to shoot ratio has been reported to decrease with use of copper compounds on the interior surface of containers (Arnold and Struve, 1989). The $\mathrm{Cu}(\mathrm{OH})_{2}$ did not promote development of a more fibrous root system in pawpaw seedlings, based on failure of the copper compound to increase lateral root DW production. In fact, in nonshaded control seedlings, lateral root weight actually declined with $\mathrm{Cu}(\mathrm{OH})_{2}$. Leaves of pawpaws grown in $\mathrm{Cu}(\mathrm{OH})_{2}$-treated containers yellowed by the end of the experiment. The leaf yellowing and reduced chl levels may have been the result of a toxic response of plants to absorbing high levels of $\mathrm{Cu}$ in the treated containers or reduced cytokinin production by pawpaw root tips (Allan and Jarrell, 1989; Arnold, 1992; Arnold and Struve, 1989). Cytokinins are produced in the root tips and are transported to the growing leaves, where they may delay senescence (Satoh et al., 1977). If seedling root tips of pawpaw were damaged when they came in contact with the $\mathrm{Cu}(\mathrm{OH})_{2}$ on the container wall, this may have impaired cytokinin production. Arnold and Young (1991) reported that $\mathrm{CuCO}_{3}$ treatment of containers increased root growth and nearly doubled the number of new root tips in containergrown apple seedlings; however, there was not a significant difference in xylem sap cytokinin level in $\mathrm{CuCO}_{3}$ treated, root pruned, and control seedlings. In this present study, we did not examine whether root tips were killed or whether new root tips were initiated when pawpaw root tips encountered the $\mathrm{Cu}(\mathrm{OH})_{2}$-treated containers.

In contrast to pawpaw seedlings grown outdoors, shading of $28 \%, 51 \%, 81 \%$, or $98 \%$ did not increase chl a, b, and p leaf concentration in plants grown in the greenhouse, only the a to $b$ ratio decreased significantly. Shade leaves generally have more chl, (Givinish, 1988) and a lower $a$ to $b$ ratio than sun leaves (Anderson, 1986; Hidema, et al., 1992). Once again, alteration of light quality in terms of red to far-red light ratio and UV light level in the greenhouse environment may have resulted in the different response in chl and a to b ratio of greenhouse grown plants compared to those grown outdoors.

In conclusion, growth

Fig. 6. Effect of shading on leaf chlorophyll (chl) concentration of pawpaw seedlings grown outdoors. (A) Leaf chl a (y = $10.808+0.169 \mathrm{x}-0.001 \mathrm{x}^{2}, R^{2}=$ $0.97, P=0.001)$, chl b, chl p, total chl $(15.787+0.234 \mathrm{x}-$ $\left.0.001 \mathrm{x}^{2}, R^{2}=0.98, P=0.002\right)$, and $(\mathbf{B})$ chl a to $\mathrm{b}$ ratio $(\mathrm{y}=$ $2.155-0.005 \mathrm{x}, R^{2}=0.93, P=$ $0.001)$. Each symbol is the mean of two blocks \pm SE.
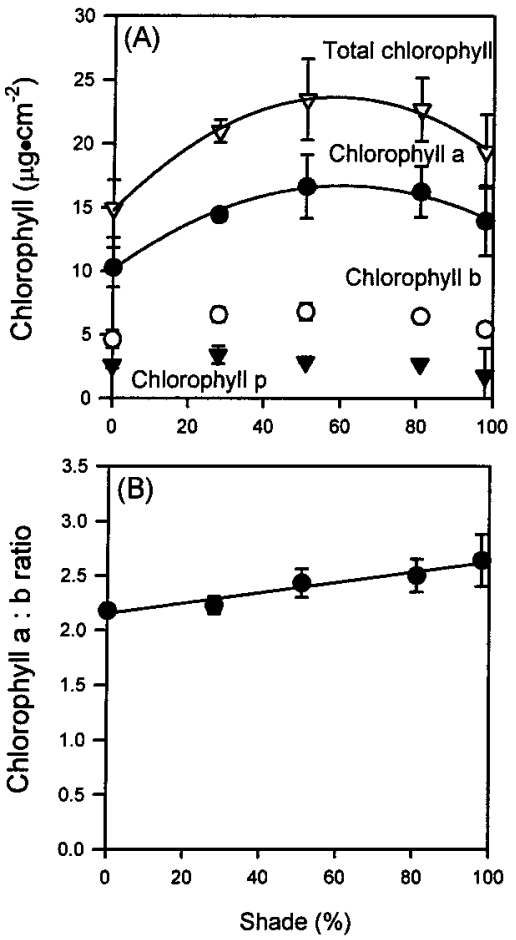
of containerized pawpaw seedlings was positively influenced by low to moderate shading ( $28 \%$ or $51 \%$ ) outdoors and low shading $(33 \%)$ in the greenhouse, in a manner typical of that reported for other shade-preferring plants. Low to moderate shading of pawpaw seedlings grown outdoors greatly increased whole plant biomass, indicating that commercial nurseries can further improve production of containerized pawpaw seedlings using this shading regime outdoors. If plants are produced on a gravel container pad, higher levels of shading $(>55 \%)$ that would also reduce air temperatures could be beneficial. Because seedlings were destructively harvested in this study, the effect of $\mathrm{Cu}(\mathrm{OH})_{2}$ on direct transplanting to the field or larger containers could not be determined. However, based on the data herein, $\mathrm{Cu}(\mathrm{OH})_{2}$ treatment of the interiors of containers used for production of pawpaw seedlings cannot be recommended at the present time.

\section{Literature Cited}

Abrams, M.D. and M.E. Kubiske. 1990. Leaf structural characteristics of 31 hardwood and conifer tree species in central Wisconsin: Influence of light regime and shade tolerance rank. Forest Ecol. and Mgt. 31:245254.

Allen, D.L. and W.M. Jarrell. 1989. Proton and copper absorption to maize and soybean root cell walls. Plant Physiol. 89:823-832.

Anderson, J.M. 1986. Photoregulation of the composition, function, and structure of thylakoid membranes. Annu. Rev. Plant Physiol. 37:93136.

Arnold, M.A. 1992. Timing, acclimation period, and cupric hydroxide concentration alter growth responses of the Ohio production system. J. Environ. Hort. 10:114-117.

Arnold, M.A. and D.K. Struve. 1989. Growing green ash and red oak in $\mathrm{CuCO}_{3}$-treated containers increases root regeneration and shoot growth following transplant. J. Amer. Soc. Hort. Sci. 114:402-406.

Arnold, M.A. and D.K. Struve. 1993. Root distribution and mineral uptake of coarse-rooted trees grown in cupric hydroxide-treated containers. HortScience 28:988-992.

Arnold, M.A. and E. Young. 1991. $\mathrm{CuCO}_{3}$-painted containers and root pruning affect apple and green ash root growth and cytokinin levels. HortScience 26:242-244.

Buisson, D. and D.W. Lee. 1993. The developmental response of papaya leaves to simulated canopy shade. Amer. J. Bot. 80:947-952.

Darrow, G.M. 1975. Minor temperate fruits, p. 276-277. In: J. Janick and J.N. Moore (eds.). Advances in fruit breeding. Purdue Univ. Press, West Lafayette, Ind.

Finneseth, C.L.H., D.R. Layne, and R.L. Geneve. 1998a. Morphological development of pawpaw [Asimina triloba (L.) Dunal] during seed germination and seedling emergence. HortScience 33:802-805.

Finneseth, C.L.H., D.R. Layne, and R.L. Geneve. 1998b. Requirements for seed germination in North American pawpaw [Asimina triloba (L.) Dunal]. Seed Sci. and Technol. 26:471-480.

Givinish, T.J. 1988. Adaptation to sun and shade: A whole-plant perspective. Aust. J. Plant. Physiol. 15:63-92.

Gonzalez, R., R. Mepsted, A.R. Wellburn, and N.D. Paul. 1998. Nonphotosynthetic mechanisms of growth reduction in pea (Pisum sativum L.) exposed to UV-B radiation. Plant. Cell. Environ. 21:23-32.

Gould, H. 1939. The native pawpaw. U.S. Dept. of Agr., Wash., D.C. Lflt. 179.

Hidema, J., A. Makino, Y. Kurita, T. Mae, and K. Ojima. 1992. Changes in the levels of chlorophyll and light-harvesting chlorophyll a/b protein of PS II in rice leaves aged under different irradiances from full expansion through senescence. Plant Cell Physiol. 33:1209-1214.

Hutchison, B.A. and D.R. Matt. 1977. The distribution of solar radiation within a deciduous forest. Ecol. Monogr. 47:185-207.

Jones, S.C, R.N. Peterson, T. Turner, K.W. Pomper, and D.R. Layne. 1998. Pawpaw planting guide: Cultivars and nursery sources. Kentucky State Univ. Pawpaw Ext. Bul. 001.

Kappel, F. and J.A. Flore. 1983. Effect of shade on photosynthesis, specific leaf weight, leaf chlorophyll content, and morphology of young peach leaves. J. Amer. Soc. Hort. Sci. 108:541-544.

Kral, R. 1960. A revision of Asimina and Deeringothamnus (Annonaceae). Brittonia 12:233-278.

Layne, D.R. 1996. The pawpaw [Asimina triloba (L.) Dunal]: A new fruit crop for Kentucky and the United States. HortScience 31:777784.

Lee, D.W. and R. Graham. 1987. Leaf optical properties in extreme shade plants. Amer. J. Bot. 73:1100-1108.

Maggs, D.H. 1960. The stability of the growth pattern of young appletrees under four levels of illumination. Ann. Bot. 24:434-450.

Moran, R. 1982. Formulae for the determination of chlorophyllous pigments extracted with N,N-dimethylformamide. Plant Physiol. 69:1376-1381.

Morgan, D.C. and H. Smith. 1976. Linear relationship between phytochrome photoequilibrium and growth in plants under simulated natural radiation. Nature 262:210-212.

Nichols, T.J. and A.A. Alm. 1983. Root development of containerreared, nursery-grown, and naturally regenerated pine seedlings. Can. J. For. Res. 13:239-245.

Peterson, R.N. 1991. Pawpaw (Asimina). In: J.N. Moore and J.R. Ballington (eds.). Genetic resources of temperate fruit and nut trees. Acta Hort. 290:567-600.

Rajapakse, N.C., R.E. Young, M.J. McMahon, and R. Oi. 1999. Plant height control by photoselective filters: Current status and future prospects. HortTechnology 9:618-624.

Ruter, J.M. 1994. Growth responses of four vigorous-rooted tree species in cupric hydroxide-treated containers. HortScience 29:1089.

Satoh, M., P. E. Kriedemann, and B.R. Loveys. 1977. Changes in photosynthetic activity and related processes following decapitation in mulberry trees (Morus alba). Physiol. Plant 41:203-210.

Sisson,W.B. and M.M. Caldwell. 1977. Atmospheric ozone depletion: Reduction of photosynthesis and growth of a sensitive higher plant exposed to enhanced UV-B radiation (Rumex patientia). J. Expt. Bot. 28:691-705

Svenson, S.E., D. L. Johnson, and B.L. Coy. 1995. Shoot and root responses of eight subtropical species grown in cupric hydroxidetreated containers. HortScience 30:249-251.

Tasker, R. and H. Smith. 1976. The function of phytochrome in the natural environment. V. Seasonal changes in radiant energy quality. Photochem. Photobiol. 16:487-491.

Vladimirova, S.V., D.B. McConnell, and M.E. Kane. 1997. Morphological plasticity of Dracaena sanderana 'Ribbon' in response to four light intensities. HortScience 32:1049-1052.

Whitcomb, C.E. 1988. Growing media, p. 464-480. In C.E. Whitcomb (ed.). Plant production in containers. Lacebark Publ., Cambridge, Mass.

Young, D.R. and J.B. Yavitt. 1987. Differences in leaf structure, chlorophyll, and nutrients for the understory tree Asimina triloba. Amer. J. Bot. 74:1487-1491. 